\section{Weapons labs turn to computer simulation}

Colin Macilwain

US nuclear weapons laboratories are moving to a regime based on linking experiment and computer simulation. But can they win over their critics?

T he Science-based Stockpile Stewardship (SBSS) programme was conceived three years ago as a political compromise to keep the laboratories functioning and consolidate political support for the Comprehensive Test Ban Treaty within the United States.

The programme is now finally taking shape inside the laboratories, which have been deprived by the treaty of their historic function of developing new nuclear weapons, and were until recently uncertain of their future.

Although a programme to install the largest supercomputers in the world has only just started, scientists at the laboratories have already developed the first versions of entirely new weapons codes which will simulate existing nuclear weapons on the parallel processing computers. The codes replace far less powerful computer programs used to design weapons on older, vector-based machines.

New experimental facilities at the laboratories have not even been built yet. Federico Peña, the energy secretary, broke ground at a ceremony to mark the start of construction of the National Ignition Facility (NIF), the largest and most significant of these, at the Lawrence Livermore National Laboratory last week. But experiments at existing facilities are being used to feed new information into these codes.

\section{Critical codes for simulation}

Fuller understanding of the behaviour of the high-explosive, plutonium fission 'primary' and hydrogen fusion 'secondary' stages of nuclear weapons, and of their other components, will enable scientists at the laboratories progressively to refine these codes.

This prospect excites scientists at the weapons laboratories. But it alarms critics in the United States and abroad, who fear that the codes will be used to develop new generations of nuclear weapons, with or without nuclear testing (see Nature 387, 439; 1997).

Randy Christensen, a senior computer scientist at Livermore, says the new computer codes "are reaching the point where they begin to deliver results". He predicts that the laboratory, having lost its old rhythm in which computer-assisted design work led up to a climactic device test at the Nevada Test Site, yielding results to feed back into the design, will now establish a new rhythm.
Indeed, a major justification of NIF and the rest of the stewardship programme is the need to attract talented scientists to the weapons laboratories. Morale plunged among weapons scientists at Livermore and at Los Alamos and Sandia, the other weapons laboratories in New Mexico, after testing stopped in 1992. But several scientists at Livermore agreed with Christensen that it is already reviving as SBSS takes shape.

Last week's ground-breaking at NIF, a \$1.2-billion laser facility that will help to underpin Livermore well into the next century, should have capped the revival. But court action by an alliance of environmental groups opposed to SBSS means that actual construction work - originally due to begin in April - has now been postponed until 27 June at the earliest.

The issue is politically contentious. Despite protests at the ground-breaking, Ellen Tauscher (Democrat, California), the newly elected congresswoman for the district containing Livermore, said that "people here are overwhelmingly supportive" of NIF construction. But other Californian politicians kept away from the ground-breaking, as did the US vice-president Al Gore.

In summarizing the case for NIF, Peña cited the support of the veteran physicists Hans Bethe and Herb York. "I am absolutely convinced that NIF is required to allow us to enter into the Comprehensive Test Ban Treaty without losing our nuclear deterrent," he said, adding that his judgement was largely based on the advice of scientists who support non-proliferation.

Prominent in that group is Sidney Drell, deputy director of the Stanford Linear Accelerator Center (SLAC), whom the previous energy secretary, Hazel O'Leary, says conprominent former weapons scientists and non-proliferation advocates - Ray Kidder, a Livermore Laboratory Associate (see Nature, 386, 645-647; 1997), and Richard Garwin, IBM fellow emeritus - have recently criticized aspects of SBSS.

Garwin and Kidder both support NIF as a science experiment. But they say that its ability to simulate conditions in the 'secondary' of a nuclear weapon has been oversold. At the same time, both hotly dispute the claim by Ted Taylor, a former weapons designer at Los Alamos and long-time anti-nuclear camvinced her of the case for SBSS. But two other

\section{IMAGE UNAVAILABLE FOR COPYRIGHT REASONS}

Breaking new ground: Energy secretary Federico Peña (centre) digs in at the ignition facility site.

paigner, that NIF is a proliferation risk that could be used to develop new types of nuclear weapon.

NIF will use 192 giant laser beams to fire a brief energy pulse of 500 terawatts of peak power at a tiny fusion target, called a hohlraum, possibly igniting a small, controlled, but self-sustaining fusion reaction.

This ignition has been the holy grail of fusion researchers for fifty years. Partialpower experiments are due to start late in 2001. Livermore scientists hold different views on how soon after that they should attempt to reach ignition.

\section{Wider than weapons research?}

Like the rest of SBSS, NIF is being paid for by the Congress as a weapons programme. But at the ground-breaking, much of the focus was on the possibilities it will offer to nonweapons scientists, including those from outside the Department of Energy laboratory system.

But NIF's main role is to serve as an anchor for the Lawrence Livermore National Laboratory - just as SBSS as a whole was conceived to support the three laboratories and their Nevada test site.

For proponents, this approach meets a critical national-security objective, attracting exceptional new talent to the weapons programme and retaining it for unknown future needs. For opponents, it is porkbarrel politics of the worst kind: the price to be paid, as Frank von Hipple, a former official in the Clinton administration, has put it, to win support of the weapons laboratories for an end to weapons testing.

Some time in the next eighteen months, the Clinton administration will need 67 votes in the Republican-controlled Senate to ratify the Comprehensive Test Ban Treaty. The administration hopes that the successful initiation of SBSS, and the flow of $\$ 4$ billion annually into the US nuclear weapons programme, will help to achieve it. 